\title{
FK228 Analogues Induce Fetal Hemoglobin in Human Erythroid Progenitors
}

\author{
Levi Makala, ${ }^{1}$ Salvatore Di Maro, ${ }^{2,3}$ Tzu-Fang Lou, ${ }^{4}$ Sharanya Sivanand, ${ }^{5}$ \\ Jung-Mo Ahn, ${ }^{2}$ and Betty S. Pace ${ }^{1}$ \\ ${ }^{1}$ Department of Pediatrics, Georgia Health Sciences University, Augusta, GA 30912, USA \\ ${ }^{2}$ Department of Chemistry, University of Texas at Dallas, Richardson, TX 75083, USA \\ ${ }^{3}$ Department of Pharmacological and Toxicological Chemistry, University of Naples Federico II, 80100 Naples, Italy \\ ${ }^{4}$ Department of Molecular and Cell Biology, University of Texas at Dallas, TX 75080, USA \\ ${ }^{5}$ Department of Developmental Biology, University of Texas Southwestern Medical Center, Dallas, TX 75390, USA
}

Correspondence should be addressed to Betty S. Pace, bpace@georgiahealth.edu

Received 16 December 2011; Accepted 7 March 2012

Academic Editor: Solomon F. Ofori-Acquah

Copyright (c) 2012 Levi Makala et al. This is an open access article distributed under the Creative Commons Attribution License, which permits unrestricted use, distribution, and reproduction in any medium, provided the original work is properly cited.

Fetal hemoglobin (HbF) improves the clinical severity of sickle cell disease (SCD), therefore, research to identify HbF-inducing agents for treatment purposes is desirable. The focus of our study is to investigate the ability of FK228 analogues to induce HbF using a novel KU812 dual-luciferase reporter system. Molecular modeling studies showed that the structure of twenty FK228 analogues with isosteric substitutions did not disturb the global structure of the molecule. Using the dual-luciferase system, a subgroup of FK228 analogues was shown to be inducers of HbF at nanomolar concentrations. To determine the physiological relevance of these compounds, studies in primary erythroid progenitors confirmed that JMA26 and JMA33 activated HbF synthesis at levels comparable to FK228 with low cellular toxicity. These data support our lead compounds as potential therapeutic agents for further development in the treatment of SCD.

\section{Introduction}

Several classes of pharmacological compounds that reactivate $\gamma$-globin gene transcription have been identified. They include cytotoxic agents, DNA methyl transferase, and histone deacetylase (HDAC) inhibitors. Cytotoxic compounds terminate actively cycling progenitors and perturb cellular growth to trigger rapid erythroid regeneration and $\gamma$-globin gene activation. S-stage cytotoxic drugs, such as cytosine arabinoside [1], myleran [2], vinblastine [3], and hydroxyurea $[4,5]$, induce $\mathrm{HbF}$ production in primates and humans $[4,6,7]$. The Multicenter Study of Hydroxyurea established this agent as the first FDA-approved treatment for SCD [7]. Hydroxyurea was shown to reduce vaso-occlusive episodes in the majority of sickle-cell patients treated. However, limitations to using hydroxyurea such as bone marrow suppression
[8], concerns over long-term carcinogenic complications, and a $30 \%$ non-response rate $[7,9]$, make the development of alternative therapies desirable.

The HDAC inhibitors have also been shown to be potent $\mathrm{HbF}$ inducers. These agents target HDACs, which play a dynamic role in regulating cell cycle progression and chromatin conformation by changes in histone acetylation status. Aberrant transcriptional repression mediated by Class I and II HDACs has been demonstrated in many cancers [10]. Thus, HDAC inhibitors have been developed as promising anticancer therapeutics [11]. Structurally diverse classes of natural and synthetic HDAC inhibitors bind target HDACs to block histone deacetylation [12] and produce an open chromatin confirmation and gene activation [13].

There has been great interest in HDAC inhibitors as $\mathrm{HbF}$ inducers to treat SCD. They include (1) short-chain 
fatty acids such as sodium butyrate $(\mathrm{NaB})$, the first HDAC inhibitor reported $[14,15]$; (2) the benzamides (i.e., MS275); (3) non cyclic and cyclic hydroxamates, like SAHA (suberoylanilide hydroxamic acid) and TSA (Trichostatin A); (4) cyclic peptides including FK228 (depsipeptide). $\mathrm{NaB}$ induces differentiation in mouse erythroleukemia cells via Stat 5 phosphorylation and $\mathrm{HbF}$ synthesis through p38 mitogen-activated protein kinase signaling [16-18]. Other fatty acids including phenylacetate and propionate [1921], induce $\mathrm{HbF}$ in erythroid progenitors, however, these agents are rapidly metabolized and oral preparations are not available. These published studies serve as the basis for research efforts to develop HDAC inhibitors as therapeutic agents for SCD.

Of the hydroxamic acid derivatives, the prototype TSA is a potent HDAC inhibitor [22, 23]. It interacts with a divalent zinc-binding motif in the binding pocket of Class I and II HDACs [24]. Other HDAC inhibitors in the hydroxamic acid class include the second-generation analogues of TSA, identified from a library screen of 600 synthesized compounds [25]. The most widely studied TSA analogues are SAHA and Scriptaid. SAHA targets HDAC1, 3, and 4 and inhibits prostate cancer cell growth in vitro and in vivo $[26,27]$. Recently, it was demonstrated by Pace and colleagues that SAHA and Scriptaid induce HbF synthesis comparable to $\mathrm{NaB}$ and TSA in erythroid cells and $\beta$-YAC transgenic mice respectively [28]. However, limitations to the further development of these agents included toxicity in primary cells.

Another potent HDAC inhibitor is FK228, also known as depsipeptide, isolated from Chromobacterium violaceum [29]. This compound has a unique bicyclic structure and is a stable pro-drug activated by the reduction of the disulfide bond by glutathione to produce an active form (redFK) after uptake into cells [30]. The reduced sulfhydryl group interacts strongly with the zinc ion at the active site of the enzyme and has been shown to inhibit tumor proliferation in vitro and in vivo at nanomolar concentrations [27, 31, 32]. Recently, FK228 was tested in the $\mu \mathrm{LCR} \beta_{\text {pr }} \mathrm{R}_{\text {luc }}{ }^{\mathrm{A}} \gamma_{\text {pr }} \mathrm{F}_{\text {luc }}$ GM979 stable cell line and erythroid progenitors grown in methylcellulose colonies produced from peripheral blood mononuclear cells [33]. FK228 was shown to induce $\mathrm{HbF}$ in both systems. The level of $\gamma$-globin and $\beta$-globin promoter activity was quantified indirectly using firefly $(\gamma)$ and renilla $(\beta)$ luciferase activity.

Drug-mediated $\mathrm{HbF}$ induction remains the best approach to ameliorate the symptoms and complications of SCD. Among many compounds, FK228 showed efficacy in inducing $\gamma$-globin transcription at low concentrations, however, cell toxicity was observed and the drug is difficult to synthesize. It is a bicyclic depsipeptide almost exclusively comprised of unnatural amino acids, D-valine, D-cysteine and, (Z)-dehydrobutyrine (Dhb) as well as a (3S, 4E)3-hydroxy-7-mercapto-4-heptenoic acid, which is a key component to form the highly constrained bicyclic structure. The high content of the unnatural amino acids and the constrained bicyclic structure make it extremely stable in physiological condition. Simon and coworkers first reported its total synthesis in 1996 [34], and suggested a laborious synthetic route with moderate yield (18\% overall yield with over 16 steps).

Despite its exceptionally high in vitro and in vivo activity, FK228 has not been explored due to its non-trivial and challenging synthesis, which hampered its production and the design of analogues. The latter would aide our understanding of the molecular mechanism of FK228 and to achieve higher potency and selectivity for $\mathrm{HbF}$ induction. In fact, only a few FK228 analogues have been created to date even after intensive synthetic efforts were made [34-36]. To circumvent this problem, we used in silico structure analysis and molecular modeling to design twenty FK228 structural analogues that can be easily synthesized [37]. Furthermore, two isosteric substitutions were made without altering its global conformation.

The objective of our study was to investigate the ability of the newly synthesized FK228 analogues to induce $\gamma$ globin gene transcription using a dual luciferase-based assay system. We identified two lead compounds, JMA26 and JMA33, which induce HbF expression in primary erythroid progenitors. The potential of HDAC enzymes as druggable targets in the treatment of SCD is discussed.

\section{Materials and Methods}

2.1. Synthesis of FK228 Analogues. The synthesis of all FK228 analogues described in this study was accomplished by following the previously reported solid-phase synthetic procedure outlined in Scheme 1 [37]. Briefly, S-trityl cysteamine was loaded on aminomethylated polystyrene (AM-PS) resin that was previously functionalized with a backbone amide linker (BAL) [38]. The resulting secondary amine 1 was then coupled with the first amino acid, Fmoc-L-Asp $(\mathrm{OAl})$ to give the aspartylcysteamine 2 with high yield (98\%). Thus, the aspartylcysteamine moiety designed to replace the heptenoic acid in the native FK228, was constructed in a single reaction step. The remaining four amino acids were introduced sequentially using the standard $\mathrm{N}-\mathrm{Fmoc} /{ }^{t} \mathrm{Bu}$ solid-phase peptide synthesis strategy to build the linear pentapeptides 6a-f. After the allyl and N-Fmoc protecting groups were removed, the macrolactams 7a-f were formed with HBTU (O-benzotriazole- $\mathrm{N}, \mathrm{N}, \mathrm{N}^{\prime}, \mathrm{N}^{\prime}$-tetramethyluronium hexafluorophosphate) as a coupling reagent with high yields and purity (>95\%). S-Trityl protecting groups were removed with dilute $1 \%$ trifluoroacetic acid and the resulting free thiols were oxidized with iodine to produce the bicyclic FK228 analogues. The analogues were cleaved from the resin with TFA $(>95 \%)$ and characterized by reverse phasehigh performance liquid chromatography and electrospray ionization mass spectrometry.

2.2. Cell Culture. Human KU812 leukemia cells were grown in Iscove's Modified Dulbecco's medium (IMDM) (Invitrogen, Carlsbad, CA) with 10\% fetal bovine serum (Atlanta Biologicals, Atlanta, GA), penicillin (100 U/mL), and streptomycin $(0.1 \mathrm{mg} / \mathrm{mL})$. The cells were incubated at $37^{\circ} \mathrm{C}$ with $5 \% \mathrm{CO}_{2}$. Cell count and viability were determined using a hemocytometer and 2\% Trypan blue exclusion. Inductions 


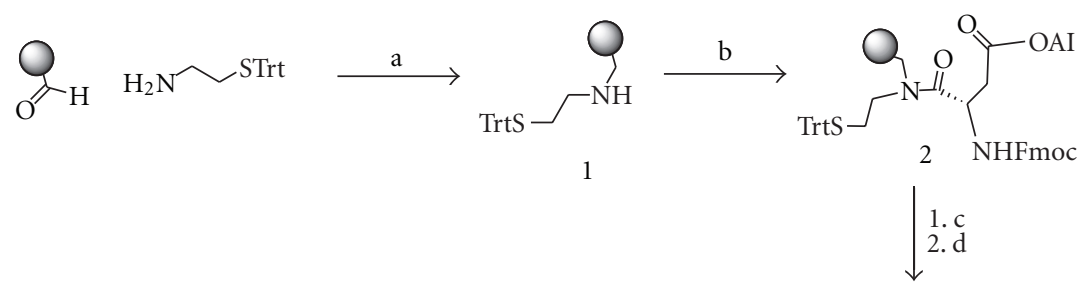

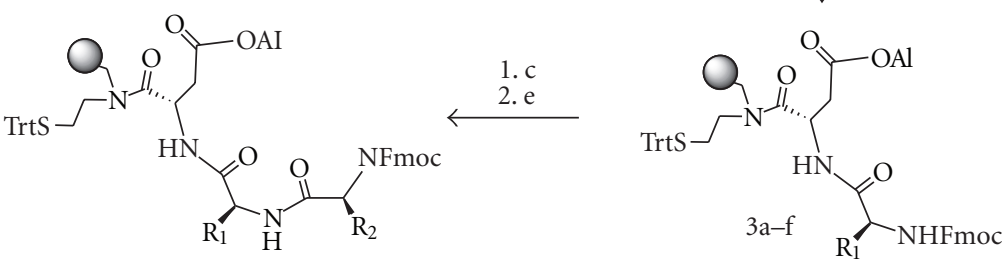<smiles>CC=C[Tl]</smiles>

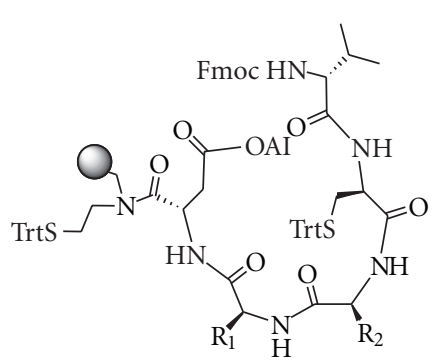

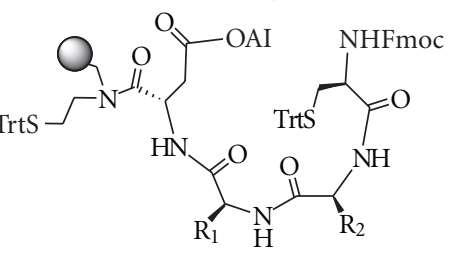<smiles>C1CC1</smiles><smiles>C1=CC2C=CC12</smiles>

$5 a-f$

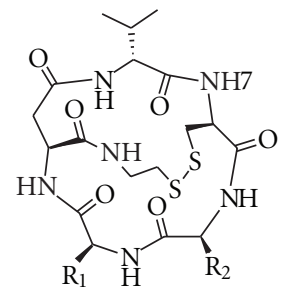<smiles>C1CCCC1</smiles>

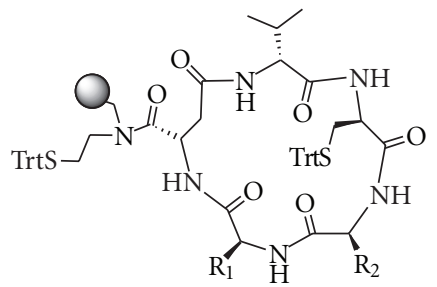

JMA 1
JMA 2
JMA 12
JMA 26
JMA 33
JMA 112

$$
\begin{aligned}
& \mathrm{R}_{1}=\mathrm{L}-\mathrm{Val}, \\
& \mathrm{R}_{1}=\mathrm{L}-\mathrm{Val}, \\
& \mathrm{R}_{1}=\mathrm{L}-\mathrm{Phe}, \\
& \mathrm{R}_{1}=\mathrm{L}-\mathrm{Phe} \\
& \mathrm{R}_{1}=\mathrm{L}-(2)-\mathrm{Na} \\
& \mathrm{R}_{1}=\mathrm{L}-\mathrm{Phe}
\end{aligned}
$$

$$
\begin{aligned}
& \mathrm{R}_{2}=\mathrm{L}-\mathrm{Ala} \\
& \mathrm{R}_{2}=\mathrm{L}-\mathrm{Phe} \\
& \mathrm{R}_{2}=\mathrm{L}-\mathrm{Ala} \\
& \mathrm{R}_{2}=\mathrm{L}-\mathrm{Phe} \\
& \mathrm{R}_{2}=\mathrm{L}-(2)-\mathrm{Nal} \\
& \mathrm{R}_{2}=\mathrm{L}-\text { Lys (FITC) }
\end{aligned}
$$

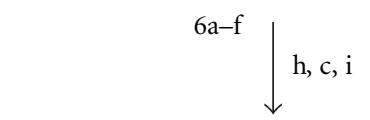

Scheme 1: Synthesis of FK228 analogues. Shown in the schematic are the steps, reagents, and conditions used for FK228 analogue synthesis. Compounds 1-7 are the intermediates during the synthesis. For steps $7 \mathrm{a}-\mathrm{f}$, the different $\mathrm{R}_{1}$ and $\mathrm{R}_{2}$ group substitutions were made to generate the various JMA analogues shown. Symbols: (a) $\mathrm{NaBH}_{3} \mathrm{CN}$; (b) Fmoc-Asp(OAl), DIC; (c) Piperidine; (d) Fmoc-AA 1 , HBTU; (e) Fmoc-AA 2 ,

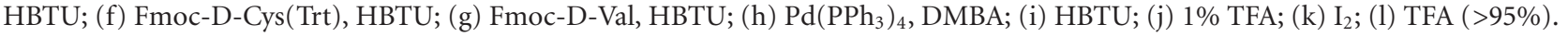

were performed with one million cells treated for $48 \mathrm{hr}$ with the following drugs purchased from Sigma (St Louis, MO): $50 \mu \mathrm{M}$ Hem (hemin), $2 \mathrm{mM} \mathrm{NaB}$ (sodium buytrate), $0.5 \mu \mathrm{M}$ TSA, $10 \mathrm{mM}$ Cys (cysteine), $1.5 \mathrm{nM}$ FK228, and $100 \mu \mathrm{M}$ HU (hydroxyurea). We also tested $5 \mu \mathrm{M}$ SAHA, a gift from Merck \& Co. Inc. (Whitehouse Station, NJ).

2.3. KU812 Stable Lines. KU812 stable cell lines were created by co-transfecting wild-type KU812 cells with pEGFP-NI (G418 selectable marker) and the $\mu \mathrm{LCR} \beta_{\mathrm{pr}} \mathrm{R}_{\mathrm{luc}}{ }^{\mathrm{A}} \gamma_{\mathrm{pr}} \mathrm{F}_{\text {luc }}$ dualreporter a kind gifts from Dr. George Stamatoyannopoulos
(University of Washington). Briefly, the 315-bp human $\beta$ globin gene promoter sequence was inserted upstream of the Renilla along with a polyadenylation signal downstream to create $\mathrm{P} \beta_{\mathrm{pr}} \mathrm{R}_{\text {luc }}$. Likewise, $1.4 \mathrm{~kb}$ of human $\mathrm{A} \gamma$-globin promoter was inserted upstream of firefly luciferase to create ${ }^{\mathrm{A}} \gamma_{\mathrm{pr}} \mathrm{F}_{\text {luc }}$. The $\mu \mathrm{LCR}$ (locus control region), $\mathrm{P} \beta_{\mathrm{pr}} \mathrm{R}_{\text {luc }}$, and ${ }^{\mathrm{A}} \gamma_{\mathrm{pr}} \mathrm{F}_{\text {luc }}$ fragments were subsequently cloned into the mammalian vector, pRL-null [39].

The dual-luciferase reporter lines were produced using $10 \mu \mathrm{g}$ each of linearized $\mu \mathrm{LCR} \beta_{\mathrm{pr}} \mathrm{R}_{\text {luc }}{ }^{\mathrm{A}} \gamma_{\mathrm{pr}} \mathrm{F}_{\text {luc }}$ and $\mathrm{p} E G F P-N I$ plasmids co-transfected into KU812 cells by electroporation 


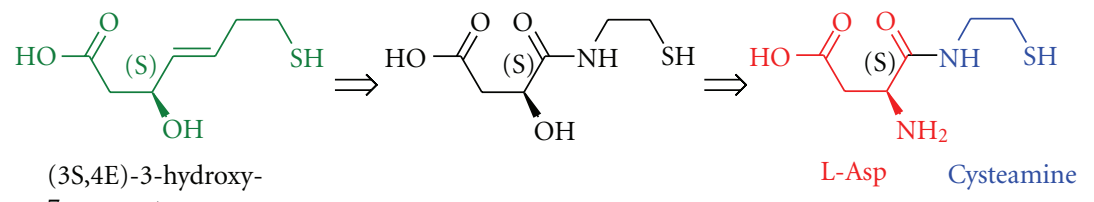

7-mercapto-

4-heptenoic acid

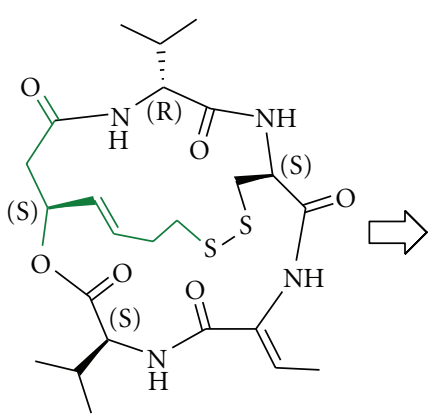

FK228

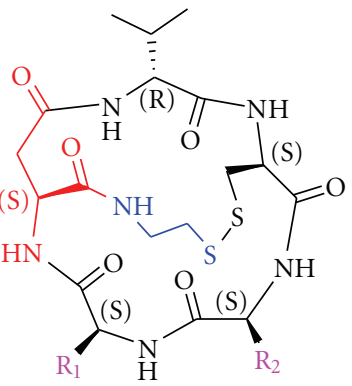

FK228 analogues

(a)

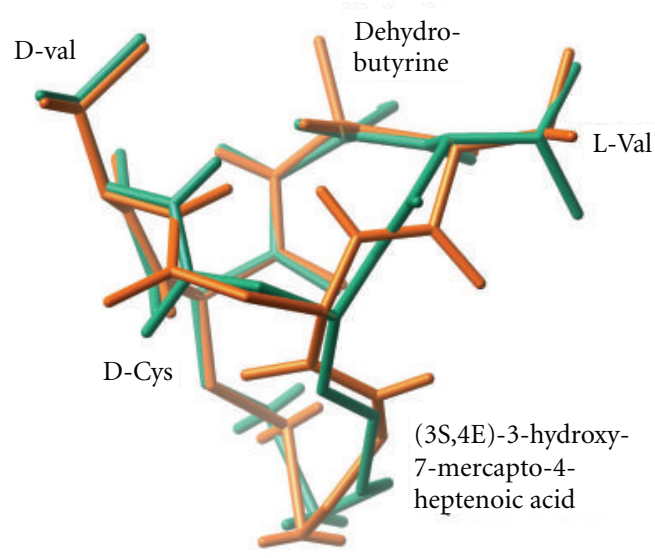

(b)

FIGURE 1: Structures of FK228 analogues. (a) The parent compound FK228 was transformed into novel structural analogues by two isosteric substitutions. The modification of the trans-double bond and ester linkage in the native FK228 with two isosteric amide functional groups allows facile synthesis of analogues as well as retention of the same backbone structure. Various amino acids such as Val, Ala, Phe, 2-Nal, and Lys were introduced to investigate potency of the analogues. (b) Superimposed structures of FK228 (green) and a modified FK228 analogue (orange).

at $260 \mathrm{~V}, 975 \mu \mathrm{F}$ (Bio-Rad, Hercules CA). After $72 \mathrm{hr}, \mathrm{G} 418$ was added at a concentration of $900 \mu \mathrm{g} / \mu \mathrm{l}$ for 3 days then maintained under selection pressure indefinitely at a concentration of $400 \mu \mathrm{g} / \mu \mathrm{l}$. KU812 stable lines were treated with the various drugs at the same concentrations described above. FK228 and analogues were screened at concentrations between 1-1000 $\mathrm{nM}$ for $48 \mathrm{hr}$ and cell toxicity was monitored by $2 \%$ Trypan blue exclusion. The effect of drug treatments on $\gamma$-globin and $\beta$-globin promoter activity was monitored by luciferase assay.

2.4. Dual Luciferase Assay. Luciferase activity was monitored under the different experimental conditions using the Dual Luciferase Assay Reporter System (Promega, Madison, WI). The activity of firefly luciferase represents $\gamma$-globin promoter activity $(\gamma \mathrm{F})$, while the renilla luciferase is the read-out for $\beta$-globin promoter activity $(\beta \mathrm{R})$. The $\beta$-globin promoter was strategically cloned between the LCR and $\gamma$-globin promoter to increase $\beta$ expression, while simultaneously increasing the sensitivity of detection of $\gamma$-globin gene inducers [40].

After drug treatments, KU812 stable cells were washed with $1 \mathrm{X}$ phosphate buffered saline and lysed in 1X Passive Lysis Buffer for $15 \mathrm{~min}$, then protein extracts were added to the Luciferase Assay Reagent II and firefly luciferase activity quantified in a Turner Designs TD-20/20 luminometer (Sunnyvale, CA). To measure $\beta$ R activity, Stop \& Glo Reagents was added to measure the renilla luciferase activity. Total protein was determined by Bradford assay on a Beckman DU 640 spectrophotometer (Chaska, MN) and luciferase activity was corrected for total protein. 


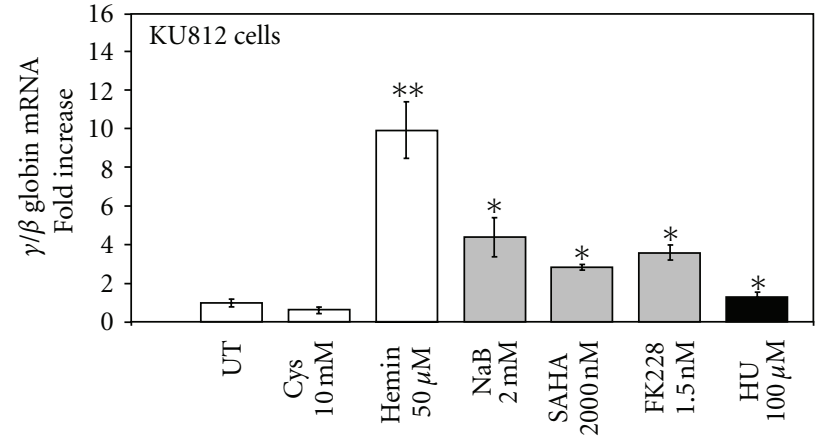

(a)

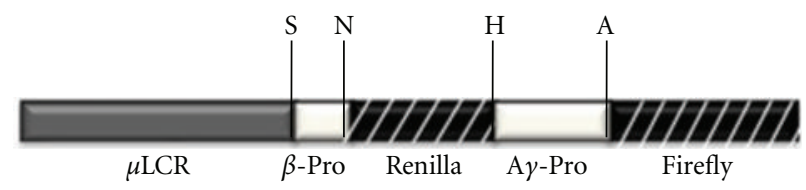

(b)

Figure 2: Known HbF inducers activate $\gamma$-globin expression in KU812 cells. (a) Induction of $\gamma$-globin transcription by known HbF inducers. Cells were treated for $48 \mathrm{hr}$ with the different drug inducers and $\gamma$-globin and $\beta$-globin gene transcription were measured by RT-qPCR (see Section 2). The relative mRNA levels were plotted as fold increase. Untreated cells (UT) were used as a control and normalized to one. Data were calculated as the means \pm standard error of the mean (SEM); ${ }^{*} P<0.05$ and ${ }^{* *} P<0.01$. (b) Shown is a schematic of the dual luciferase reporter construct $\mu \mathrm{LCR} \beta_{\mathrm{pr}} \mathrm{R}_{\mathrm{luc}} \gamma_{\mathrm{pr}} \mathrm{F}_{\text {luc }}$ which contains a 3.1-kb $\mu \mathrm{LCR}$ cassette linked to a 315-bp human $\beta$-globin gene promoter driving the renilla luciferase gene and a $1.4-\mathrm{kb} A \gamma$ promoter driving the firefly luciferase gene $[33,39]$.

2.5. Two-Phase Erythroid Liquid Culture System. The twophase liquid culture system was established as previously published by Fibach et al. [41] using buffy coat mononuclear cells, purchased from Carter Blood Care (Fort Worth, TX) in accordance with the guidelines of the Institutional Review Board at the University of Texas at Dallas. During phase 1, cells were grown in IMDM medium with $30 \%$ fetal bovine serum and $50 \mathrm{ng} / \mathrm{mL}$ each of the granulocyte-monocyte colony-stimulating factor, Interleukin-3, and stem cell factor. Subsequently, phase 2 was initiated on day 7 with the addition of erythropoietin $(2 \mathrm{U} / \mathrm{mL})$ and stem cell factor $(50 \mathrm{ng} / \mathrm{mL})$. The cells were treated on Day 11 with the different test compounds and harvested on Day $14(72 \mathrm{hr}$ incubation).

2.6. Reverse Transcription-Quantitative PCR (RT-qPCR) Analysis. Total RNA was isolated from samples using RNA Stat-60 (TEL-TEST "B" Inc., Friendswood, TX) and used for RT-qPCR analysis as previously published [42]. Briefly, cDNA was prepared using the Improm-II reverse transcriptase system and oligo $(\mathrm{dT})_{15}$ primers (Promega). qPCR was performed on an iCycler iQ machine (Bio-Rad) using a master mix containing Sybergreen iQ Supermix (BioRad) and $100 \mathrm{pM}$ of each gene-specific primer pairs for $\gamma$ globin, $\beta$-globin and the internal control GAPDH. Standard curves were generated using serial 10-fold dilutions of Topo7 base plasmids carrying a $\gamma$-globin cDNA sequence (Topo7- $\gamma$-globin), Topo7- $\beta$-globin, and Topo7-GAPDH. The globin mRNA levels were calculated as a ratio of GAPDH $(\gamma / \mathrm{GAPDH}, \beta / \mathrm{GAPDH})$, and the $\gamma / \beta$-globin mRNA ratio was calculated by dividing $\gamma /$ GAPDH by $\beta /$ GAPDH.

2.7. Immunohistochemistry. Primary erythroid progenitor cytospin cell preparations were fixed with $4 \%$ paraformaldehyde in phosphate buffered saline for $15 \mathrm{~min}$, washed, and then permeabilized with $0.3 \%$ Trition- 100 solution for $10 \mathrm{~min}$. Cells were then blocked in a $5 \%$ bovine serum albumin solution and immunostaining performed at $4^{\circ} \mathrm{C}$ overnight with anti-HbF fluorescein isothiocyanate (FITC) conjugated antibody (Bethyl Laboratories Inc., TX). Cell nuclei were stained with mounting medium containing 4',6diamidino-2-phenylindole (DAPI; Santa Cruz Biotechnology, CA). Primary cells were photographed with an Olympus BX 51 phase contrast epifluorescent microscope equipped with Hoffman Modulation optics. Phase-contrast images were recorded with a CCD camera ( $1 / 100$ sec exposure) and fluorescence images were photographed through 485/520 nm emission filter. The percent of $\mathrm{HbF}$ positive cells was calculated by dividing the number of FITC positive cells by total cells (DAPI positive).

2.8. Enzyme-Linked Immunosorbent Assay (ELISA). Total hemoglobin was quantified using $20 \mu \mathrm{L}$ of protein extract from one million KU812 cells mixed with $5 \mathrm{~mL}$ of Drabkin's reagent (Sigma); then cyanmethemoglobin was measured at the $540 \mathrm{~nm}$ wavelength. HbF levels were quantified using the human Hemoglobin F ELISA Quantitation Kit (Bethyl Laboratory, Montgomery, TX). Briefly, 96-well plates were coated with sheep anti-human $\mathrm{HbF}$ antibody $(1 \mathrm{mg} / \mathrm{mL})$. After blocking with $1 \%$ bovine serum albumin, horse radish peroxidase-conjugated secondary antibody $(1 \mathrm{mg} / \mathrm{mL})$ was added. Raw data were analyzed using GraphPad PRISM (GraphPad Software, Inc., La Jolla, CA) and HbF levels were calculated as a ratio of total hemoglobin corrected for total protein $(\mathrm{HbF} /$ total $\mathrm{Hb} /$ total protein).

2.9. HDAC Inhibition Assay. The HDAC Fluorescent Activity Assay (Enzo Life Science, Farmingdale, NY) was used to measure HDAC inhibition in HeLa cells in a 96-well format using Trichostatin A as the positive control per the manufacturer's protocol. This assay is based on the Fluor de Lys (Fluorogenic Histone Deacetylase Lysyl (FDL)) Substrate/ Developer. The procedure was as follows: the test compounds FK228, JMA26, and JMA33 were added to HeLa cells along 


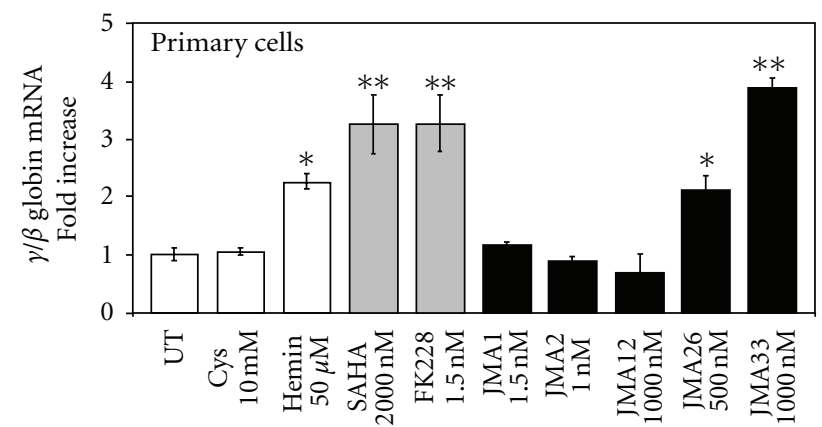

(a)

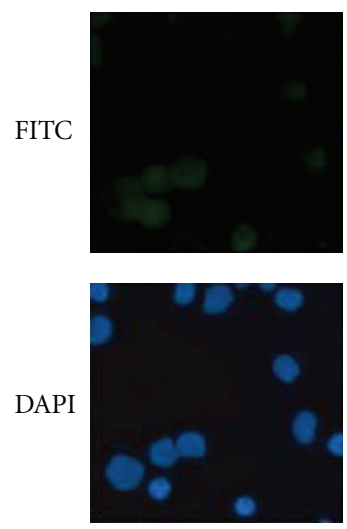

Untreated
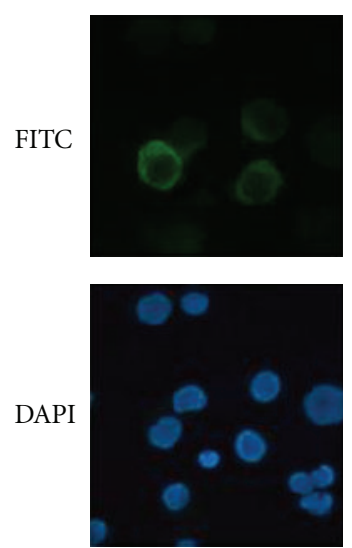

JMA1
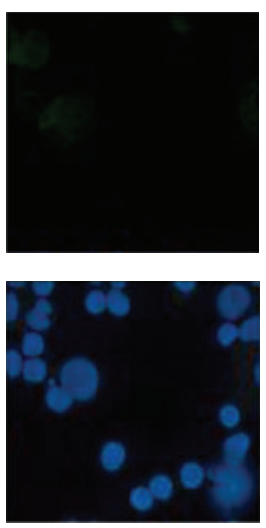

Cysteine
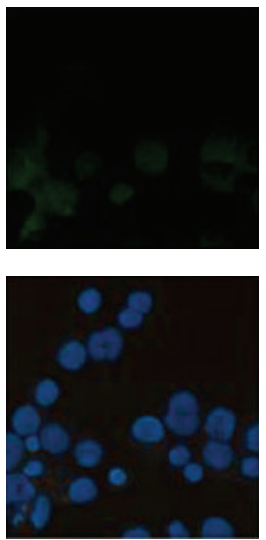

JMA2
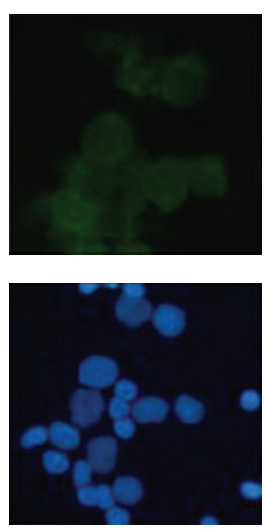

Hemin
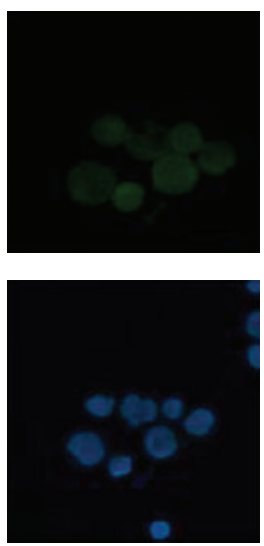

JMA12
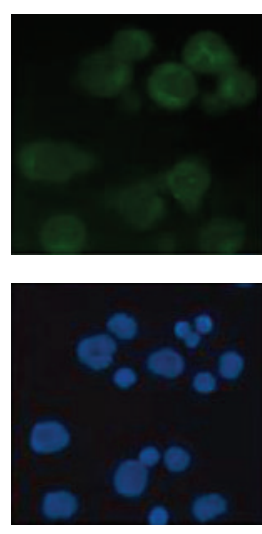

SAHA
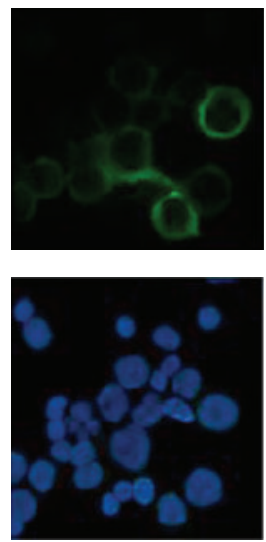

JMA26
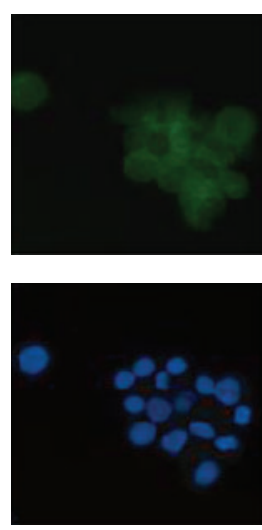

FK228
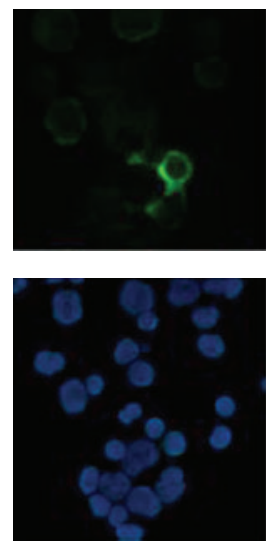

JMA33

(b)

FIGURE 3: JMA33 and JMA26 induce HbF in primary erythroid cells. (a) Day 11 erythroid progenitors were treated for 48 hr with the controls agents and the FK228 analogues shown and then analyzed by RT-qPCR. Untreated cells (UT) were used as a control and normalized to one. Data were calculated as the means \pm SEM. (b) Progenitors were stained with anti- $\gamma$-globin FITC conjugated antibody overnight and HbF positive cells for were visualized. DAPI staining was performed to identify cell nuclei and to determine cell counts. Images were photographed at $40 \mathrm{X}$ power. The images generated were used to count 500 DAPI positive cells and the \%FITC positive cells were calculated accordingly.

with the FDL substrate to allow intracellular drug activation then fluorescence levels were read on the fluorometer at $440 \mathrm{~nm}$ (CytoFluor II, PerSeptive Biosystems, Farmingdale, NY). The drug concentrations tested were based on the amount required for $\mathrm{HbF}$ induction in primary cells. Data was reported as the mean \pm standard deviation (SD) for at least five replicates.
2.10. Statistical Analysis. The data are reported as the mean \pm standard error of the mean (SEM) from at least five data points generated from independent drug treatments. Data were analyzed by a two-tailed student's $t$-test, and values of $P<0.05$ were considered statistically significant. Statistical analyses were performed using Microsoft Excel (Redmond, WA, USA). 


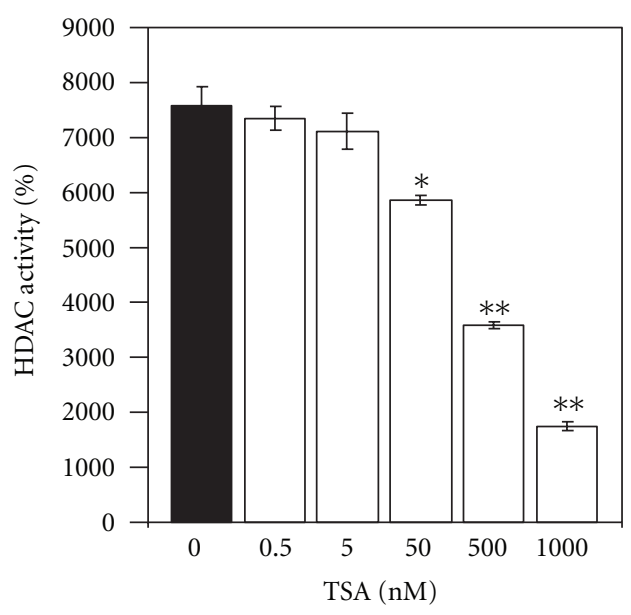

(a)

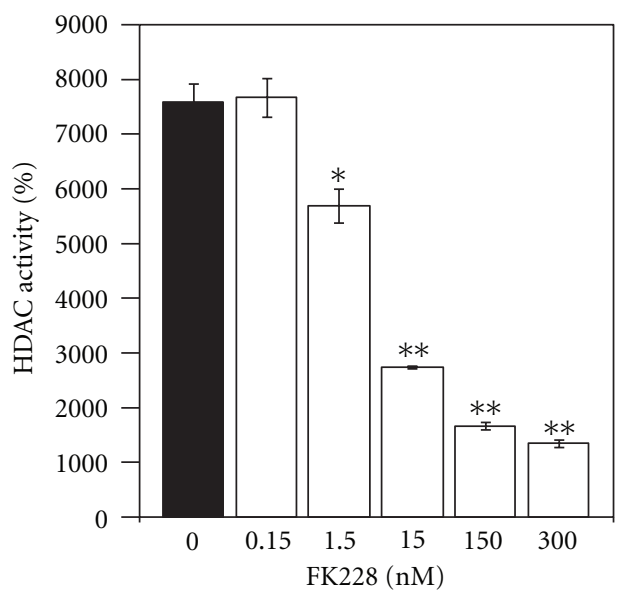

(b)

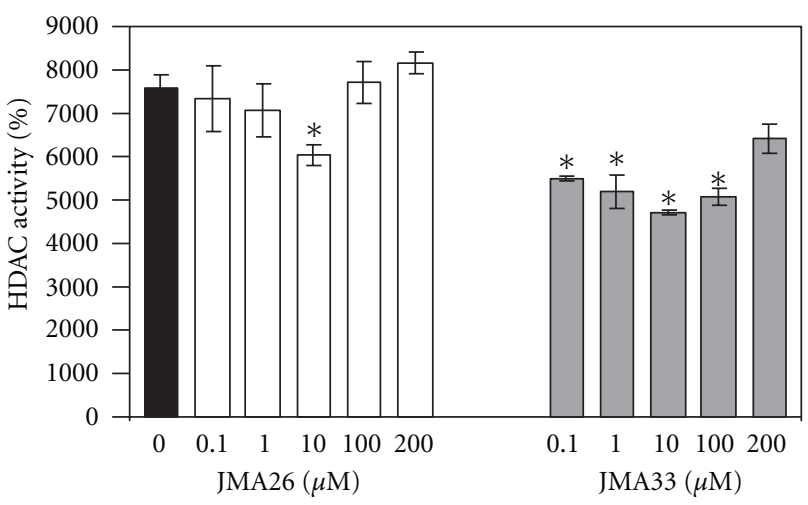

(c)

Figure 4: HDAC inhibition assay. The HDAC Fluorescent Activity Assay was used to measure HDAC inhibition in HeLa cells (See Section 2). Compounds and FDL substrate were added to HeLa cells to allow drug activation in vivo then fluorescence levels were quantified on the fluorometer at $440 \mathrm{~nm}$. (a) Trichostatin A (TSA) was used as the control. (b) Inhibition studies were conducted for FK228 showing maximal HDAC inhibition at the $300 \mathrm{nM}$ concentration. (c) Similar studies were performed for JMA33 and JMA26. The data are reported as the means \pm SEM.

\section{Results}

3.1. Isosteric Substitutions Do Not Alter the Global Structure of FK228. For the facile synthesis of FK228 analogues, the most synthetically challenging moiety, hydroxy-mercaptoheptenoic acid was modified to a structure that can be easily constructed but has the capability of retaining the structure required for biological activity. We used in silico structure analysis and molecular modeling to design structural analogues of FK228 that met these requirements and could be easily synthesized [37]. The design of a novel FK228 analogue is summarized in Figure 1. These compounds were synthesized by modifying the most synthetically challenging unit, (3S,4E)-3-hydroxy-7-mercaptoheptenoic acid, with two isosteric substitutions without altering its global conformation compared to native FK228. First, the transdouble bond in the heptenoic acid was replaced by an isosteric amide bond. Second, the ester bond required to form the depsipeptide was replaced by another amide bond for facile ring closure that provided higher synthetic yield and increased in vivo stability. As shown in Figure 1(b), the structure of the FK228 analogue was found to be almost identical in structure ( $\mathrm{RMSD}=0.20 \AA$ ), indicating that the two isosteric changes neither disturbed the global structure nor altered the backbone structure compared to FK228. However, these changes enabled facile and rapid synthesis using readily available starting materials and high-yielding reactions. While retaining the original stereochemical configurations, the functional groups $\mathrm{R}_{1}$ and $\mathrm{R}_{2}$ (Figure $1(\mathrm{~b})$ ) were substituted with a variety of amino acids such as Ala, Leu, Phe, 2-Nal, Thr, Asp, and Lys (Scheme 1) to examine the side chain consisting of small, large, aromatic, hydrophilic, and charged alterations.

Twenty FK228 analogues were prepared with high overall yield (75-90\%) and purity (80-94\%) using the solid-phase synthetic strategy. To further characterize the compounds, selected FK228 analogues were examined by 2D-NMR spectroscopy in (dimethyl sulfoxide) DMSOd$_{6}$ using Doublequantum filtered, total correlation, and rotating frame Overhauser effect spectroscopy to confirm structures and stereochemistry (data not shown). The FK228 analogues were shown to have outstanding solubility $(10 \mathrm{mM})$ in the 
TABLE 1: $\gamma$-globin induction in KU812- $\gamma \mathrm{F} / \beta \mathrm{R}$ stable lines by FK228 derivatives ${ }^{1}$.

\begin{tabular}{|c|c|c|c|c|c|}
\hline Line 1 & $\begin{array}{c}\text { Drug } \\
\text { concentration }\end{array}$ & $\begin{array}{l}\gamma / \gamma+2 \beta \\
\text { Mean }\end{array}$ & SEM & $P$ value & $\begin{array}{l}\text { Fold } \\
\text { change }\end{array}$ \\
\hline Untreated & none & 0.0402 & 0.0091 & $\mathrm{n} / \mathrm{a}$ & 1 \\
\hline Cys & $10 \mathrm{mM}$ & 0.0388 & 0.0092 & 0.8528 & 0.950 \\
\hline Hemin & $50 \mu \mathrm{M}$ & 0.1732 & 0.0399 & 0.0050 & 4.325 \\
\hline SAHA & $2000 \mathrm{nM}$ & 0.2157 & 0.0142 & 0.0001 & 5.400 \\
\hline FK228 & $1.5 \mathrm{nM}$ & 0.1197 & 0.0325 & 0.0150 & 2.975 \\
\hline $1127 \mathrm{Ox}$ & $1000 \mathrm{nM}$ & 0.0363 & 0.0022 & 0.8167 & 0.900 \\
\hline JMA1 & $1.5 \mathrm{nM}$ & 0.0473 & 0.0149 & 0.6720 & 1.175 \\
\hline JMA2 & $1.0 \mathrm{nM}$ & 0.0157 & 0.0003 & 0.1629 & 0.400 \\
\hline JMA12 & $1000 \mathrm{nM}$ & 0.0187 & 0.0009 & 0.2156 & 0.475 \\
\hline JMA26 & $500 \mathrm{nM}$ & 0.1460 & 0.0234 & 0.0004 & 3.650 \\
\hline JMA33 & $1000 \mathrm{nM}$ & 0.1373 & 0.0117 & 0.0002 & 3.425 \\
\hline JMA112 & $100 \mathrm{nM}$ & 0.0187 & 0.0007 & 0.2156 & 2.453 \\
\hline Line 2 & $\begin{array}{c}\text { Drug } \\
\text { concentration }\end{array}$ & $\begin{array}{c}\gamma / \gamma+2 \beta \\
\text { Mean }\end{array}$ & SEM & $P$ value & $\begin{array}{l}\text { Fold } \\
\text { change }\end{array}$ \\
\hline Untreated & none & 0.1573 & 0.0150 & $\mathrm{n} / \mathrm{a}$ & 1 \\
\hline Cys & $10 \mathrm{mM}$ & 0.1200 & 0.0056 & 0.1977 & 0.764 \\
\hline Hemin & $50 \mu \mathrm{M}$ & 0.6593 & 0.0839 & 0.0001 & 4.261 \\
\hline SAHA & $2000 \mathrm{nM}$ & 0.6500 & 0.0208 & 0.0001 & 4.140 \\
\hline FK228 & $1.5 \mathrm{nM}$ & 0.6167 & 0.0338 & 0.0001 & 3.929 \\
\hline $1127 \mathrm{Ox}$ & $1000 \mathrm{nM}$ & 0.6133 & 0.0371 & 0.0001 & 3.904 \\
\hline JMA1 & $1.5 \mathrm{nM}$ & 0.1260 & 0.0152 & 0.2896 & 0.803 \\
\hline JMA2 & $1.0 \mathrm{nM}$ & 0.1183 & 0.0071 & 0.1814 & 0.752 \\
\hline JMA12 & $1000 \mathrm{nM}$ & 0.1470 & 0.0027 & 0.7093 & 0.936 \\
\hline JMA26 & $500 \mathrm{nM}$ & 0.2487 & 0.0308 & 0.0153 & 1.579 \\
\hline JMA33 & $1000 \mathrm{nM}$ & 0.3313 & 0.0256 & 0.0002 & 2.108 \\
\hline JMA112 & $100 \mathrm{nM}$ & 0.1070 & 0.0076 & 0.0938 & 0.682 \\
\hline Line 3 & $\begin{array}{c}\text { Drug } \\
\text { concentration } \\
\end{array}$ & $\begin{array}{c}\gamma / \gamma+2 \beta \\
\text { Mean }\end{array}$ & SEM & $P$ value & $\begin{array}{c}\text { Fold } \\
\text { change }\end{array}$ \\
\hline Untreated & none & 0.0721 & 0.0052 & $\mathrm{n} / \mathrm{a}$ & 1 \\
\hline Cys & $10 \mathrm{mM}$ & 0.0860 & 0.0050 & 0.1814 & 1.194 \\
\hline Hemin & $50 \mu \mathrm{M}$ & 0.2508 & 0.0153 & 0.0001 & 3.486 \\
\hline SAHA & $2000 \mathrm{nM}$ & 0.2520 & 0.0066 & 0.0001 & 3.500 \\
\hline FK228 & $1.5 \mathrm{nM}$ & 0.1583 & 0.0198 & 0.0007 & 2.194 \\
\hline $1127 \mathrm{Ox}$ & $1000 \mathrm{nM}$ & 0.0370 & 0.0095 & 0.0076 & 0.514 \\
\hline JMA1 & $1.5 \mathrm{nM}$ & 0.0770 & 0.0036 & 0.6179 & 1.069 \\
\hline JMA2 & $1.0 \mathrm{nM}$ & 0.0740 & 0.0036 & 0.8463 & 1.027 \\
\hline JMA12 & $1000 \mathrm{nM}$ & 0.0537 & 0.0023 & 0.0779 & 0.750 \\
\hline JMA26 & $500 \mathrm{nM}$ & 0.2560 & 0.0192 & 0.0001 & 3.555 \\
\hline JMA33 & $1000 \mathrm{nM}$ & 0.5120 & 0.1765 & 0.0007 & 7.111 \\
\hline JMA112 & $100 \mathrm{nM}$ & 0.0467 & 0.0019 & 0.0216 & 0.653 \\
\hline
\end{tabular}

${ }^{1}$ Using three independent KU812- $\gamma \mathrm{F} / \beta \mathrm{R}$ stable cell lines, the FK228 analogues were examined for their ability to induce $\gamma$-globin. After $48 \mathrm{hr}$ drug treatments, cells were harvested and dual luciferase assay performed. Untreated cells were used as a control and normalized to one. Data were calculated as the means \pm standard error of the mean (SEM).

organic solvents ethanol and DMSO and were stable for over one year.

3.2. FK228 Analogues Are Potent Inducers of $\gamma$-Globin Expression. We first performed drug induction studies in wild type KU812 cells to determine the ability of analogues to induce endogenous $\gamma$-globin gene transcription. KU812 cells have been classified as a multipotential leukemia cell line with the ability to differentiate down the basophilic [43, 44], eosinophilic [45] and erythroid/megakaryocytic 
lineages [46]. Previous studies from our laboratory demonstrated that KU812 cells express $\gamma$-globin, $\beta$-globin and the erythroid markers CD36, and erythropoietin receptor [47]. Therefore, we used these cells to perform initial drug screens to determine the suitability of KU812 cells for our dual luciferase reporter stable lines. We observed a 1.5- to10 -fold increase in the $\gamma / \beta$-globin mRNA levels after Hem $(50 \mu \mathrm{M}), \mathrm{NaB}(2 \mathrm{mM})$, SAHA $(2 \mu \mathrm{M}))$, and FK228 $(1.5 \mathrm{nM})$ treatment (Figure 2(a)). In the untreated and negative controls, cysteine-treated cells, $\gamma$-globin gene expression was not induced. These data demonstrated that the intracellular environment in KU812 is conducive to identifying $\gamma$-globin gene activators in our FK228 analogue drug screen.

Subsequently, three independent dual-luciferase reporter KU812 stable cell lines were established to analyze the ability FK228 analogues to induce $\gamma$-globin promoter activity without an effect on $\beta$-globin transcription. The stable cell lines were created with the $\mu \mathrm{LCR} \beta_{\mathrm{pr}} \mathrm{R}_{\mathrm{luc}} \gamma_{\mathrm{pr}} \mathrm{F}_{\text {luc }}$ construct (Figure 2(b)) containing a 3.1-kb $\mu$ LCR cassette linked to a 315-bp human $\beta$-globin promoter driving the renilla (R) and a 1.4-kb A $\gamma$-globin promoter driving the firefly (F) luciferase genes $[33,39]$. Since the firefly luciferase gene $(\gamma \mathrm{F})$ has approximately $50 \%$ greater luminescence than the renilla gene $(\beta R)$, the renilla activity was multiplied by two to adjust for the difference in luminescence [33] yielding the $\gamma / \gamma+2 \beta$ final measurement. The FK228 analogues were examined at concentrations ranging from $1-1000 \mathrm{nM}$ in the three stable lines. After 48-hour treatments, cells were harvested and protein isolated for luciferase activity using the Dual Luciferase Reporter Assay. Of the twenty compounds tested, five induced $\gamma$-promoter activity. The remaining agents were either toxic at the concentrations tested or did not induce $\gamma$-globin (data not shown). Table 1 summarizes the $\gamma$-promoter activity for FK228 analogues that were tested further in primary erythroid cells. Cell viability by Trypan blue exclusion remained at $90-95 \%$ for the concentrations shown. Of note are the FK228 analogues, JMA26 and JMA33 (Table 2) containing aromatic side chains in the functional $R_{1}$ and $R_{2}$ groups which produced statistically significant $\gamma$-promoter activation comparable to FK228. Additional analogues can be designed based on these observations to increase potency, while sparing toxicity.

\subsection{FK228 Analogues Activate HbF Synthesis in Primary} Erythroid Progenitors. Next, we examined the ability of the lead FK228 analogues to induce HbF expression in primary erythroid progenitors grown from peripheral blood mononuclear cells in the two-phase liquid culture system. As shown in Figure 3(a), JMA26 and JMA33 induced $\gamma$ globin transcription at the mRNA level 2.1-fold and 3.9-fold, respectively, compared to a maximal 3.2 -fold, induction by SAHA and FK228. However, FK228 derivatives induce $\gamma$ promoter activity at significantly lower drug concentrations compared to SAHA and Hem. At the concentrations tested, greater than $90 \%$ cell viability was observed in primary cells at all concentrations tested for the synthesized compounds. The similarity of these results to those acquired with the KU812 dual-luciferase reporter cell lines also validates the system for drug screening.
TABLE 2: FK228 structural analogues.

\begin{tabular}{lcc}
\hline FK228 analogues & $\mathrm{R}_{1}$ & $\mathrm{R}_{2}$ \\
\hline JMA1 & Val & Ala \\
JMA2 & Val & Phe \\
JMA12 & Phe & Ala \\
JMA26 & Phe & Phe \\
JMA33 & 2Nal & 2Nal \\
JMA112 & Phe & Lys(FITC) \\
\hline
\end{tabular}

Val: valine; Phe: phenylalanini; Ala: alanine; 2Nal: 2-naphthylmethyl; Lys: lysine; FITC: fluorescein isothiocyanate.

The next set of studies was performed to determine the ability of JMA26 and JMA33 to induce HbF in primary erythroid progenitors. Using anti-HbF fluorescein isothiocyanate (FITC) antibody, we observed 15.5\% HbF-positive progenitors at baseline in untreated cells (Figure 3(b)). Treatment with JMA26 and JMA33 produced 3.0-fold, and 2.5-fold increase in HbF-positive cells, respectively. A similar increase in HbF-positive cells, were produced by hemin, SAHA and FK228 (3.0-fold, 3.2-fold and 3.5-fold). Complementary ELISA data (Table 3) showed a 1.9-fold and 2.5-fold increase in $\mathrm{HbF}$ levels produced by JMA26 and JMA33, respectively, compared to a 2.4 -fold $\mathrm{HbF}$ induction by FK228. We concluded that these lead compounds have the capability to induce $\mathrm{HbF}$ in physiologically normal primary erythroid progenitors.

3.4. JMA26 and JMA33 Exhibit HDAC Inhibition Activity. To ascertain the mechanism of HbF induction by the lead compounds, we performed an in vivo assay to investigate the ability of JMA26 and JMA33 to act as HDAC inhibitors. The HDAC Fluorescent Activity Assay designed to measure HDAC activity in HeLa cells was completed in a 96-well format. The assay is based on the fact that the Fluor de Lys substrate is deacetylated by HDACs to generate a fluorescent readout. TSA ( 0.5 to $1000 \mathrm{nM}$ ) was used to establish the assay in HeLa cells, showing about 80\% HDAC inhibition in our system (Figure 4(a)). By contrast, FK228 produced about $85 \%$ inhibition at the $300 \mathrm{nM}$ concentration, which produces marked cell toxicity (Figure 4(b)). Similar studies performed for JMA26 and JMA33 showed 20\% and 37\% HDAC inhibition, respectively (Figure 4(c)), suggesting $\mathrm{HbF}$ induction in erythroid cells occurs by other mechanisms.

\section{Discussion}

Drug-mediated HbF induction remains the best treatment approach to ameliorate the symptoms and complications of SCD due to its ability to inhibit hemoglobin S polymerization. In addition, $\mathrm{HbF}$ provides an effective treatment for $\beta$-thalassemia by correcting globin chain imbalance [48]. Other therapies aimed at the underlying molecular causes of the $\beta$-hemoglobinopathies include hematopoietic stem cell transplantation [49] and gene therapy involving the transfer of normal $\gamma$-or $\beta$-globin genes into hematopoietic stem cells. Despite promising results and ongoing research, the option for stem cell transplantation is limited by the lack of suitable 
TABLE 3: Fetal hemoglobin quantification in primary erythroid cells.

\begin{tabular}{lccccc}
\hline & $\begin{array}{c}\text { Drug } \\
\text { concentration }\end{array}$ & Mean & SEM & $P$ value & $\begin{array}{c}\text { Fold } \\
\text { change }\end{array}$ \\
\hline Untreated & none & 0.683 & 0.0291 & n/a & 1 \\
Cys & $10 \mathrm{mM}$ & 0.737 & 0.1201 & 0.7773 & 1.079 \\
Hemin & $50 \mu \mathrm{M}$ & 1.515 & 0.0405 & 0.0001 & 2.218 \\
SAHA & $2000 \mathrm{nM}$ & 1.094 & 0.1049 & 0.0197 & 1.602 \\
FK228 & $1.5 \mathrm{nM}$ & 1.676 & 0.0506 & 0.0001 & 2.454 \\
JMA1 & $1.5 \mathrm{nM}$ & 0.7953 & 0.0849 & 0.2803 & 1.164 \\
JMA2 & $1.0 \mathrm{nM}$ & 0.8120 & 0.0165 & 0.0183 & 1.188 \\
JMA26 & $500 \mathrm{nM}$ & 1.3086 & 0.0535 & 0.0005 & 1.916 \\
JMA33 & $1000 \mathrm{nM}$ & 1.7223 & 0.0725 & 0.0002 & 2.521 \\
\hline
\end{tabular}

donors for the majority of SCD patients. On the other hand, gene therapy offers a universal cure but there are concerns about mutagenesis of target genes due to random vector integration and the effects of viral sequences on nearby gene expression [50]. Therefore, pharmacologic $\mathrm{HbF}$ induction remains a viable choice for the development of additional therapeutic options for treating SCD.

Hydroxyurea is the only drug approved by the Food and Drug Administration for the treatment of SCD [7, 51], however, it is not effective in all patients [7] and of minimal benefit in $\beta$-thalassemia [52]. Moreover, there are concerns about undesirable side effects including long-term carcinogenesis [53]. Clinical trials with other compounds, such as arginine butyrate [54] and decitabine [55] have shown considerable promise, however, orally active preparations need to be developed to make these agents viable treatment alternatives.

For many years, K562 cells have been used to screen pharmacological agents as potential $\mathrm{HbF}$ inducers. For example, $\mathrm{NaB}$, decitabine, and hydroxyurea, among others, stimulate erythroid differentiation in K562 cells and induce $\gamma$-globin gene transcription [56]. Many HDAC inhibitors including FK228 are also known to induce HbF. However, synthetic difficulties associated with FK228 production have severely deterred structure-activity studies to aid understanding of its mechanism of action and to improve efficacy. Our data shows that JMA26 and JMA33 increased HbF levels by a mechanism independent of HDAC inhibition.

Many published studies have shown that primary erythroid cells remain the best system to confirm HbF-inducing agents and to serve as a predictor of efficacy in vivo. Human burst forming units-erythroid cells in clonogenic assays [57] or erythroid progenitors grown in liquid culture [39, 41] - have been used to evaluate putative $\mathrm{HbF}$ inducers. However, these assays are not easily adaptable to largescale drug screening, thus immortalized cell lines have been investigated for this purpose. Previously, FK228 was tested in the $\mu \mathrm{LCR} \beta_{\mathrm{pr}} \mathrm{R}_{\text {luc }}{ }^{A} \gamma_{\mathrm{pr}} \mathrm{F}_{\text {luc }}$ GM979 stable line [33] and was shown to induce $\gamma$-promoter activity at the $1 \mathrm{nM}$ concentration. We expanded on these studies to establish a dual-luciferase reporter system. Thus, we used KU812 cells derived from an individual with chronic myeloid leukemia
[58] because both $\gamma$-globin and $\beta$-globin are actively transcribed [47]. Moreover, gene profiling data generated by our laboratory showed that KU812 cells express CD36 and the erythropoietin receptor at levels comparable to day-14 human erythroid progenitors [47].

In this study, when wild-type KU812 cells were treated with Hem, NaB, SAHA, and FK228, we observed a 3- to 10 -fold increase in the $\gamma / \beta$-globin ratio. We next tested the FK228 analogues in the KU812 dual-luciferase reporter system created with the $\mu \mathrm{LCR} \beta_{\mathrm{pr}} \mathrm{R}_{\text {luc }}{ }^{\mathrm{A}} \gamma_{\mathrm{pr}} \mathrm{F}_{\text {luc }}$ construct. Two FK228 analogues identified in the reporter assay, JMA26 and JMA33, showed efficacy as $\mathrm{HbF}$ inducer in primary erythroid progenitors suggesting these compounds have the potential for further development.

Our last set of experiments was aimed at understanding the mechanism by which JMA26 and JMA33 induce $\gamma$ globin. Histone acetylation is a highly dynamic reversible modification that contributes to gene expression through changes in chromatin conformations. The parent compound FK228 is a class IV cyclic peptide capable of inhibiting Class I HDAC enzymes (HDAC1, 2, 3, and 8) after intracellular reduction of its disulfide bond by glutathione to produce the active reduced form of FK228. The functional sulfhydryl group fits inside the catalytic pocket producing zinc chelation and inhibition of enzymatic activity [59].

The role of HDAC inhibition in HbF induction has been investigated by several laboratories. $\mathrm{NaB}$ was the first agent shown to mediate histone $\mathrm{H} 3$ and $\mathrm{H} 4$ hyperacetylation as a mechanism of $\mathrm{HbF}$ induction [60]. Subsequently, many other HDAC inhibitors such as TSA [42], scriptaid [28], SBHA (suberohydroxamic acid), and SAHA (suberoylanilide hydroxamic acid) [59] were shown to be HbF inducers based on the central role of histone hyperacetylation. Subsequently, Perrine and colleagues showed the ability of short-chain fatty acids to induce $\gamma$-globin by displacement of an HDAC3NcoR repressor complex [61]. More recently, there exist chemical genetic screen-identified HDAC1 and HDAC2 as molecular targets facilitating drug-mediated $\mathrm{HbF}$ induction [62]. Therefore, to determine the mechanism of action of JMA26 and JMA33, we completed the HDAC inhibition assay.

Using the Fluor de Lys system, FK228 produced strong HDAC inhibition but at a higher concentration $(300 \mathrm{nM})$ than required for $\mathrm{HbF}$ induction. Similar studies performed for JMA26 and JMA33 showed $20 \%$ and $37 \%$ maximal inhibition, respectively. These findings suggest that the alterations in FK228 structure may have uncoupled HDAC inhibition activity as the primary mechanism of $\mathrm{HbF}$ induction since higher test drug concentrations did not produce more HDAC inhibition. These data suggests JMA26 and JMA33 may induce $\gamma$-globin by mechanisms other than targeting HDACs. Since the FK228 analogues were developed from a structural library designed by molecular modeling, additional compounds can be synthesized with greater $\mathrm{HbF}$ inducing potency and selectivity to Class I HDACs. Additional studies will also be conducted to determine other mechanisms by JMA26 and JMA33 that induce HbF such as activation of the p38 mitogen-activated protein kinase or other signaling pathways $[17,63,64]$. 


\section{Conclusions}

The current drug treatment options for SCD are limited with hydroxyurea being the only FDA-approved drug. The key finding of this study is the high-efficiency synthesis of FK228 analogues with structural modifications which did not disturb the global chemical structure of the parent compound. The analogues exhibited $\mathrm{HbF}$ induction at nanomolar concentrations in primary erythroid progenitors demonstrating physiological relevance. These data support the FK228 analogues as potential therapeutic agents and also validates the KU812 dual-luciferase stable cell lines as an efficacious screening system to identify $\gamma$-globin activators. Long-term our goal is to establish a group of $\mathrm{HbF}$ inducers that selectively inhibit Class I HDACs to expand our understanding of epigenetic mechanisms of $\gamma$-globin gene regulation and to facilitate the development of drug therapy for SCD.

\section{Acknowledgment}

This work was supported by a Grant from the National Heart Lung and Blood Institute (R01HL069234; BSP), the Francis J. Tedesco Distinguished Chair in Pediatric Hematology/Oncology (BSP), and the Robert A. Welch Foundation (AT-1595; JMA).

\section{References}

[1] T. Papayannopoulou, A. Torrealba De Ron, and R. Veith, "Arabinosylcytosine induces fetal hemoglobin in baboons by perturbing erythroid cell differentiation kinetics," Science, vol. 224, no. 4649, pp. 617-619, 1984.

[2] D. P. Liu, C. C. Liang, Z. H. Ao et al., "Treatment of severe $\beta$-thalassemia (patients) with myleran," American Journal of Hematology, vol. 33, no. 1, pp. 50-55, 1990.

[3] R. Veith, T. Papayannopoulou, S. Kurachi, and G. Stamatoyannopoulos, "Treatment of baboon with vinblastine: insights into the mechanisms of pharmacologic stimulation of hb $\mathrm{f}$ in the adult," Blood, vol. 66, no. 2, pp. 456-459, 1985.

[4] R. Galanello, G. Stamatoyannopoulos, and Papayannopoulou Th., "Mechanism of hb $\mathrm{f}$ stimulation by s-stage compounds. in vitro studies with bone marrow cells exposed to 5-azacytidine, ara-c, or hydroxyurea," Journal of Clinical Investigation, vol. 81, no. 4, pp. 1209-1216, 1988.

[5] N. L. Letvin, D. C. Linch, and G. P. Beardsley, "Augmentation of fetal-hemoglobin production in anemic monkeys by hydroxyurea," New England Journal of Medicine, vol. 310, no. 14, pp. 869-873, 1984.

[6] M. H. Steinberg, F. Barton, O. Castro et al., "Effect of hydroxyurea on mortality and morbidity in adult sickle cell anemia: risks and benefits up to 9 years of treatment," Journal of the American Medical Association, vol. 289, no. 13, pp. 16451651, 2003.

[7] S. Charache, M. L. Terrin, R. D. Moore et al., "Effect of hydroxyurea on the frequency of painful crises in sickle cell anemia. Investigators of the Multicenter Study of Hydroxyurea in Sickle Cell Anemia," The New England Journal of Medicine, vol. 332, pp. 1317-1322, 1995.

[8] M. H. Steinberg, Z. H. Lu, F. B. Barton, M. L. Terrin, S. Charache, and G. J. Dover, "Fetal hemoglobin in sickle cell anemia: determinants of response to hydroxyurea," Blood, vol. 89, no. 3, pp. 1078-1088, 1997.

[9] X. De La Cruz, S. Lois, S. Sánchez-Molina, and M. A. Martínez-Balbás, "Do protein motifs read the histone code?" Bioessays, vol. 27, no. 2, pp. 164-175, 2005.

[10] P. A. Marks and X. Jiang, "Histone deacetylase inhibitors in programmed cell death and cancer therapy," Cell Cycle, vol. 4, no. 4, pp. 549-551, 2005.

[11] C. Monneret, "Histone deacetylase inhibitors," European Journal of Medicinal Chemistry, vol. 40, no. 1, pp. 1-13, 2005.

[12] K. N. Prasad, "Butyric acid: a small fatty acid with diverse biological functions," Life Sciences, vol. 27, no. 15, pp. 13511358, 1980.

[13] A. E. Smith, P. J. Hurd, A. J. Bannister, T. Kouzarides, and K. G. Ford, "Heritable gene repression through the action of a directed dna methyltransferase at a chromosomal locus," Journal of Biological Chemistry, vol. 283, no. 15, pp. 98789885, 2008.

[14] S. D. Gore and M. A. Carducci, "Modifying histones to tame cancer: clinical development of sodium phenylbutyrate and other histone deacetylase inhibitors," Expert Opinion on Investigational Drugs, vol. 9, no. 12, pp. 2923-2934, 2000.

[15] T. Yamashita, H. Wakao, A. Miyajima, and S. Asano, "Differentiation inducers modulate cytokine signaling pathways in a murine erythroleukemia cell line," Cancer Research, vol. 58, no. 3, pp. 556-561, 1998.

[16] O. Witt, K. Sand, and A. Pekrun, "Butyrate-induced erythroid differentiation of human k562 leukemia cells involves inhibition of erk and activation of p38 map kinase pathways," Blood, vol. 95, no. 7, pp. 2391-2396, 2000.

[17] B. S. Pace, X. H. Qian, J. Sangerman et al., "P38 map kinase activation mediates $\gamma$-globin gene induction in erythroid progenitors," Experimental Hematology, vol. 31, no. 11, pp. 1089-1096, 2003.

[18] S. Torkelson, B. White, D. V. Faller, K. Phipps, C. Pantazis, and S. P. Perrine, "Erythroid progenitor proliferation is stimulated by phenoxyacetic and phenylalkyl acids," Blood Cells, Molecules, and Diseases, vol. 22, no. 2, pp. 150-158, 1996.

[19] G. J. Dover, S. Brusilow, and S. Charache, "Induction of fetal hemoglobin production in subjects with sickle cell anemia by oral sodium phenylbutyrate," Blood, vol. 84 , no. 1, pp. 339343, 1994.

[20] E. Liakopoulou, C. A. Blau, Q. Li et al., "Stimulation of fetal hemoglobin production by short chain fatty acids," Blood, vol. 86, no. 8, pp. 3227-3235, 1995.

[21] N. Tsuji, M. Kobayashi, and K. Nagashima, "A new antifungal antibiotic, trichostatin," Journal of Antibiotics, vol. 29, no. 1, pp. 1-6, 1976.

[22] M. Yoshida, M. Kijima, M. Akita, and T. Beppu, "Potent and specific inhibition of mammalian histone deacetylase both in vivo and in vitro by trichostatin a," Journal of Biological Chemistry, vol. 265, no. 28, pp. 17174-17179, 1990.

[23] M. S. Finnin, J. R. Donigian, A. Cohen et al., "Structures of a histone deacetylase homologue bound to the tsa and saha inhibitors," Nature, vol. 401, no. 6749, pp. 188-193, 1999.

[24] V. M. Richon, S. Emiliani, E. Verdin et al., "A class of hybrid polar inducers of transformed cell differentiation inhibits histone deacetylases," Proceedings of the National Academy of Sciences of the United States of America, vol. 95, no. 6, pp. 30033007, 1998.

[25] L. M. Butler, D. B. Agus, H. I. Scher et al., "Suberoylanilide hydroxamic acid, an inhibitor of histone deacetylase, suppresses the growth of prostate cancer cells in vitro and in vivo," Cancer Research, vol. 60, no. 18, pp. 5165-5170, 2000. 
[26] P. A. Marks, V. M. Richon, R. Breslow, and R. A. Rifkind, "Histone deacetylase inhibitors as new cancer drugs," Current Opinion in Oncology, vol. 13, no. 6, pp. 477-483, 2001.

[27] H. Ueda, H. Nakajima, Y. Hori et al., "Fr901228, a novel antitumor bicyclic depsipeptide produced by chromobacterium violaceum no. 968. i. taxonomy, fermentation, isolation, physico-chemical and biological properties, and antitumor activity," Journal of Antibiotics, vol. 47, no. 3, pp. 301-310, 1994.

[28] J. Johnson, R. Hunter, R. McElveen, X. H. Qian, B. S. Baliga, and B. S. Pace, "Fetal hemoglobin induction by the histone deacetylase inhibitor, scriptaid," Cellular and Molecular Biology, vol. 51, no. 2, pp. 229-238, 2005.

[29] R. Furumai, A. Matsuyama, N. Kobashi et al., "Fk228 (depsipeptide) as a natural prodrug that inhibits class i histone deacetylases," Cancer Research, vol. 62, no. 17, pp. 4916-4921, 2002.

[30] J. J. Xiao, J. Byrd, G. Marcucci, M. Grever, and K. K. Chan, "Identification of thiols and glutathione conjugates of depsipeptide fk228 (fr901228), a novel histone protein deacetylase inhibitor, in the blood," Rapid Communications in Mass Spectrometry, vol. 17, no. 8, pp. 757-766, 2003.

[31] H. Kosugi, M. Ito, Y. Yamamoto et al., "In vivo effects of a histone deacetylase inhibitor, $\mathrm{fk} 228$, on human acute promyelocytic leukemia in nod/shi-scid/scid mice," Japanese Journal of Cancer Research, vol. 92, no. 5, pp. 529-536, 2001.

[32] K. A. Fecteau, M. E. I. Jianxun, and H. C. Wang, "Differential modulation of signaling pathways and apoptosis of rastransformed 10t1/2 cells by the depsipeptide fr901228," Journal of Pharmacology and Experimental Therapeutics, vol. 300, no. 3, pp. 890-899, 2002.

[33] H. Cao and G. Stamatoyannopoulos, "Histone deacetylase inhibitor fk228 is a potent inducer of human fetal hemoglobin," American Journal of Hematology, vol. 81, no. 12, pp. 981-983, 2006.

[34] K. W. Li, J. Wu, W. Xing, and J. A. Simon, "Total synthesis of the antitumor depsipeptide fr-901,228," Journal of the American Chemical Society, vol. 118, no. 30, pp. 7237-7238, 1996.

[35] T. J. Greshock, D. M. Johns, Y. Noguchi, and R. M. Williams, "Improved total synthesis of the potent hdac inhibitor FK228 (FK-901228)," Organic Letters, vol. 10, no. 4, pp. 613-616, 2008.

[36] A. A. Bowers, T. J. Greshook, N. West et al., "Synthesis and conformation-activity relationships of the peptide isosteres of fk228 and largazole," Journal of the American Chemical Society, vol. 131, no. 8, pp. 2900-2905, 2009.

[37] S. Di Maro, R. C. Pong, J. T. Hsieh, and J. M. Ahn, “Efficient solid-phase synthesis of fk 228 analogues as potent antitumoral agents," Journal of Medicinal Chemistry, vol. 51, no. 21, pp. 6639-6641, 2008.

[38] K. J. Jensen, J. Alsina, M. F. Songster, J. Vágner, F. Albericio, and G. Barany, "Backbone amide linker (BAL) strategy for solid-phase synthesis of c-terminal-modified and cyclic peptides," Journal of the American Chemical Society, vol. 120, no. 22, pp. 5441-5452, 1998.

[39] E. Skarpidi, G. Vassilopoulos, Q. Li, and G. Stamatoyannopoulos, "Novel in vitro assay for the detection of pharmacologic inducers of fetal hemoglobin," Blood, vol. 96, no. 1, pp. 321326, 2000.

[40] C. Y. Gui and A. Dean, "Acetylation of a specific promoter nucleosome accompanies activation of the $\varepsilon$-globin gene by $\beta$-globin locus control region HS2," Molecular and Cellular Biology, vol. 21, no. 4, pp. 1155-1163, 2001.
[41] E. Fibach, L. P. Burke, A. N. Schechter, C. T. Noguchi, and G. P. Rodgers, "Hydroxyurea increases fetal hemoglobin in cultured erythroid cells derived from normal individuals and patients with sickle cell anemia or $\beta$ - thalassemia," Blood, vol. 81, no. 6, pp. 1630-1635, 1993.

[42] J. Sangerman, S. L. Moo, X. Yao et al., "Mechanism for fetal hemoglobin induction by histone deacetylase inhibitors involves $\gamma$-globin activation by creb1 and atf-2," Blood, vol. 108, no. 10, pp. 3590-3599, 2006.

[43] T. Fukuda, K. Kishi, Y. Ohnishi, and A. Shibata, "Bipotential cell differentiation of ku-812: evidence of a hybrid cell line that differentiates into basophils and macrophage-like cells," Blood, vol. 70, no. 3, pp. 612-619, 1987.

[44] K. Kishi, "A new leukemia cell line with Philadelphia chromosome characterized as basophil precursors," Leukemia Research, vol. 9, no. 3, pp. 381-390, 1985.

[45] M. Yamashita, A. Ichikawa, Y. Katakura et al., "Induction of basophilic and eosinophilic differentiation in the human leukemic cell line ku812," Cytotechnology, vol. 36, no. 1-3, pp. 179-186, 2001.

[46] M. Nakazawa, M. T. Mitjavila, N. Debili et al., "Ku 812: a pluripotent human cell line with spontaneous erythroid terminal maturation,” Blood, vol. 73, no. 7, pp. 2003-2013, 1989.

[47] S. Zein, W. Li, V. Ramakrishnan et al., "Identification of fetal hemoglobin-inducing agents using the human leukemia ku812 cell line," Experimental Biology and Medicine, vol. 235, no. 11, pp. 1385-1394, 2010.

[48] D. G. Nathan and R. B. Gunn, "Thalassemia: the consequences of unbalanced hemoglobin synthesis," the American Journal of Medicine, vol. 41, no. 5, pp. 815-830, 1966.

[49] M. Bhatia and M. C. Walters, "Hematopoietic cell transplantation for thalassemia and sickle cell disease: past, present and future," Bone Marrow Transplantation, vol. 41, no. 2, pp. 109$117,2008$.

[50] C. E. Dunbar, "The yin and yang of stem cell gene therapy: insights into hematopoiesis, leukemogenesis, and gene therapy safety," Hematology/the Education Program of the American Society of Hematology. American Society of Hematology. Education Program, pp. 460-465, 2007.

[51] M. H. Steinberg, Z. H. Lu, F. B. Barton, M. L. Terrin, S. Charache, and G. J. Dover, "Fetal hemoglobin in sickle cell anemia: determinants of response to hydroxyurea," Blood, vol. 89, no. 3, pp. 1078-1088, 1997.

[52] H. Fathallah, M. Sutton, and G. F. Atweh, "Pharmacological induction of fetal hemoglobin: why haven't we been more successful in thalassemia?" Annals of the New York Academy of Sciences, vol. 1054, pp. 228-237, 2005.

[53] S. C. Davies and A. Gilmore, "The role of hydroxyurea in the management of sickle cell disease," Blood Reviews, vol. 17, no. 2, pp. 99-109, 2003.

[54] G. F. Atweh, M. Sutton, I. Nassif et al., "Sustained induction of fetal hemoglobin by pulse butyrate therapy in sickle cell disease," Blood, vol. 93, no. 6, pp. 1790-1797, 1999.

[55] Y. Saunthararajah, R. Molokie, S. Saraf et al., "Clinical effectiveness of decitabine in severe sickle cell disease," British Journal of Haematology, vol. 141, no. 1, pp. 126-129, 2008.

[56] R. Mabaera, R. J. West, S. J. Conine et al., "A cell stress signaling model of fetal hemoglobin induction: what doesn't kill red blood cells may make them stronger," Experimental Hematology, vol. 36, no. 9, pp. 1057-1072, 2008.

[57] P. Constantoulakis, G. Knitter, and G. Stamatoyannopoulos, "On the induction of fetal hemoglobin by butyrates: in vivo and in vitro studies with sodium butyrate and comparison of 
combination treatments with 5-AZAC and ARAC," Blood, vol. 74, no. 6, pp. 1963-1971, 1989.

[58] A. Goga, J. McLaughlin, D. E. H. Afar, D. C. Saffran, and O. N. Witte, "Alternative signals to ras for hematopoietic transformation by the bcr- abl oncogene," Cell, vol. 82, no. 6, pp. 981-988, 1995.

[59] R. Furumai, A. Matsuyama, N. Kobashi et al., "FK228 (depsipeptide) as a natural prodrug that inhibits class i histone deacetylases," Cancer Research, vol. 62, no. 17, pp. 4916-4921, 2002.

[60] H. Fathallah, R. S. Weinberg, Y. Galperin, M. Sutton, and G. F. Atweh, "Role of epigenetic modifications in normal globin gene regulation and butyrate-mediated induction of fetal hemoglobin," Blood, vol. 110, no. 9, pp. 3391-3397, 2007.

[61] R. Mankidy, D. V. Faller, R. Mabaera et al., "Short-chain fatty acids induce $\gamma$-globin gene expression by displacement of a hdac3-ncor repressor complex," Blood, vol. 108, no. 9, pp. 3179-3186, 2006.

[62] J. E. Bradner, R. Mak, S. K. Tanguturi et al., "Chemical genetic strategy identifies histone deacetylase 1 (HDAC1) and HDAC2 as therapeutic targets in sickle cell disease," Proceedings of the National Academy of Sciences of the United States of America, vol. 107, no. 28, pp. 12617-12622, 2010.

[63] O. Witt, K. Sand, and A. Pekrun, "Butyrate-induced erythroid differentiation of human k562 leukemia cells involves inhibition of ERK and activation of p38 map kinase pathways," Blood, vol. 95, no. 7, pp. 2391-2396, 2000.

[64] O. Witt, S. Mönkemeyer, K. Kanbach, and A. Pekrun, "Induction of fetal hemoglobin synthesis by valproate: modulation of mapkinase pathways," American Journal of Hematology, vol. 71, no. 1, pp. 45-46, 2002. 


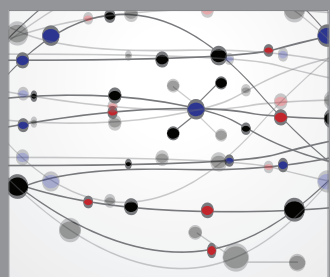

The Scientific World Journal
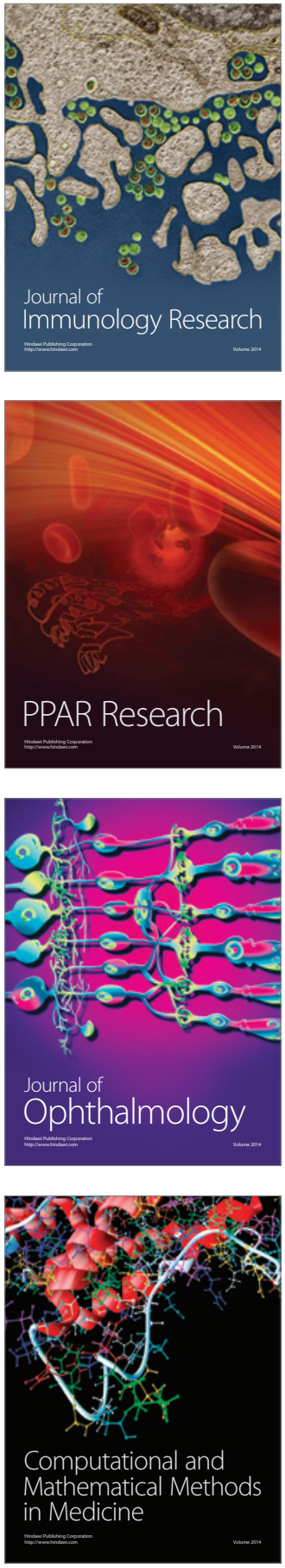

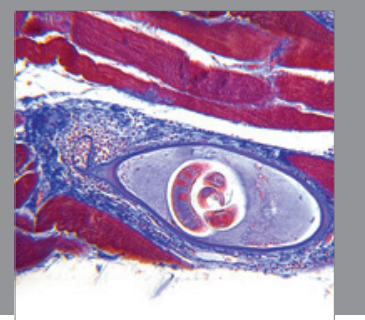

Gastroenterology

Research and Practice
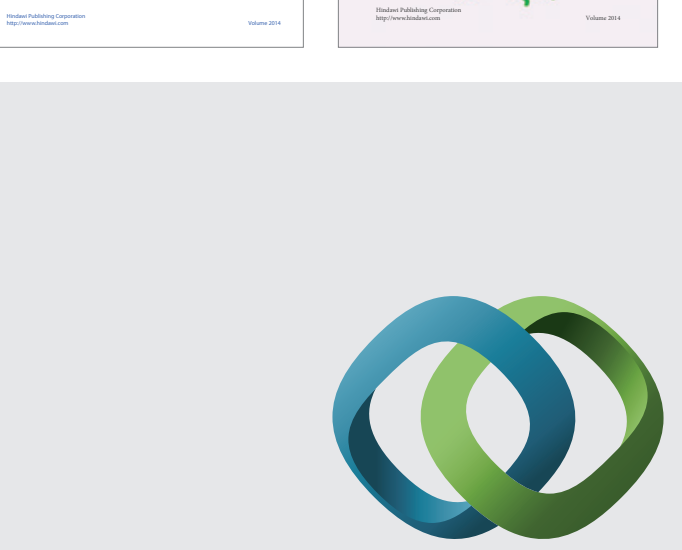

\section{Hindawi}

Submit your manuscripts at

http://www.hindawi.com
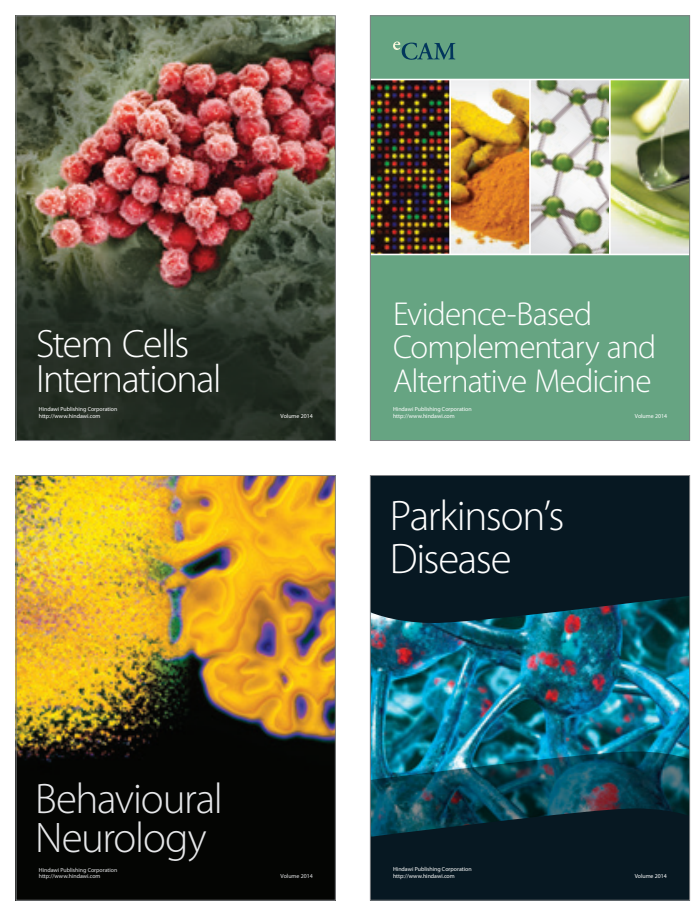

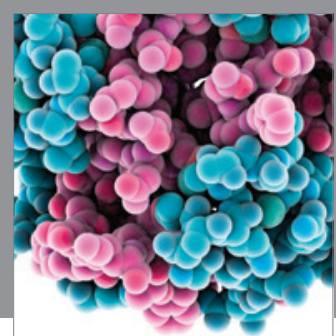

Journal of
Diabetes Research

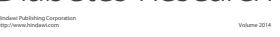

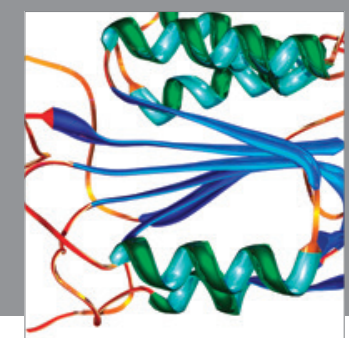

Disease Markers
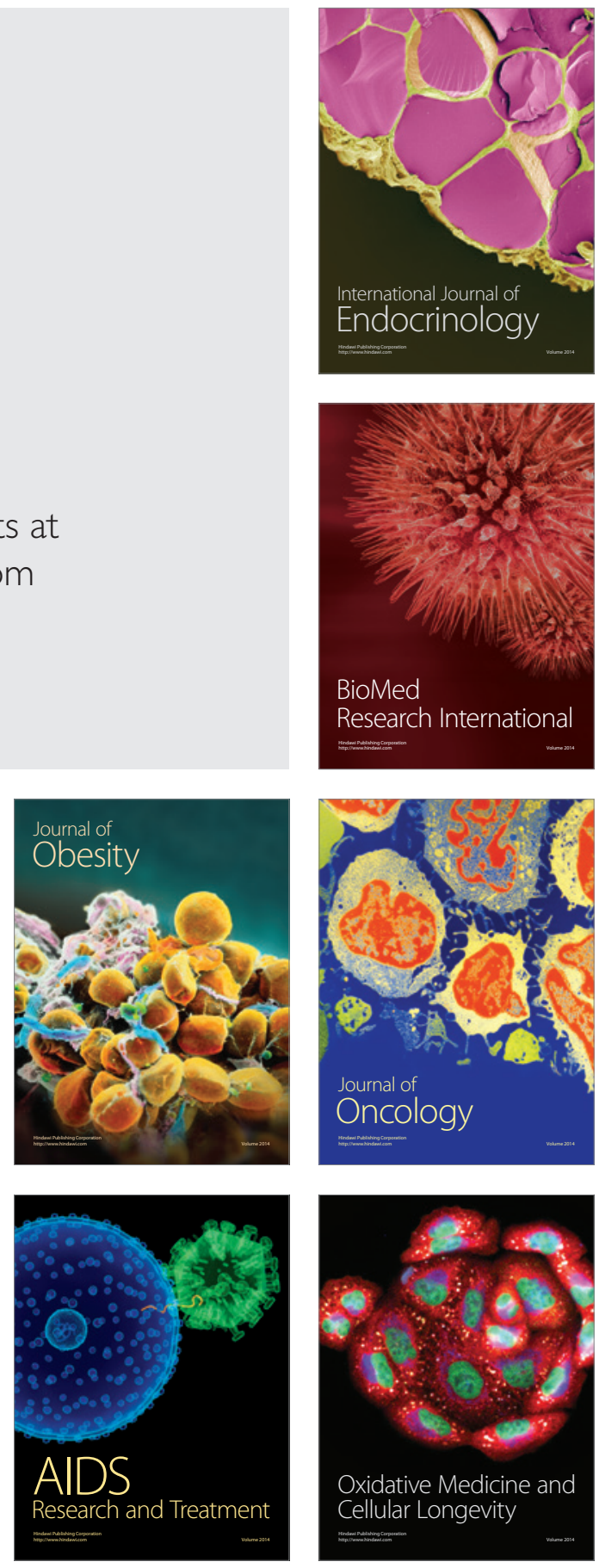